RAINBOW Vol. 10 (1) 2021
UNNES
Culture Studies
Chttps://journal.unnes.ac.id/sju/index.php/rainbow

\title{
Integrating Peace Education in Literature Class
}

\author{
Imas Istiani $^{\circledR}$, Zuhrul Anam $^{2}$ \\ 1, 2 English Department, Faculty of Languages and Arts, Universitas Negeri Semarang, Indonesia
}

\begin{tabular}{ll}
\hline Article Info & Abstract \\
\hline Article History: & The increasing cases of terrorism and extremism unite practitioners and theoreticians \\
Received & to put serious attention to the role of education for peacebuilding. However, finding \\
1 April 2021 & an appropriate strategy connecting literature education to peacebuilding is challenging. \\
Approved & Thus, the study explored the effectiveness of engaging suitable literary works to be \\
22 April 2021 & used at schools to convey a peaceful message through To Kill a Mockingbird (TKAM) \\
Published & and The Kite Runner (TKR). The study was conducted in 4 classes of Literary Work \\
23 April 2021 & Analysis course of IAIN Syekh Nurjati students in the second semester of 2018/2019 \\
& by applying Wahyudin's (2018) five factors of peace education implementation in the \\
\hline $\begin{array}{l}\text { Keywords: peace } \\
\text { education, teaching }\end{array}$ & $\begin{array}{l}\text { classrooms. The study aimed to 1) investigate how to integrate peace education into } \\
\text { literature, To Kill a }\end{array}$ \\
$\begin{array}{l}\text { Mockingbird, The Kite } \\
\text { Runner }\end{array}$ & $\begin{array}{l}\text { integrated literature class. It was found that applying peace education should consider } \\
\text { 1) objectives, 2) subject contents, 3) methods and strategies, 4) media, and 5) learning }\end{array}$ \\
& $\begin{array}{l}\text { evaluation. Students also perceived and learned about peace education by addressing } \\
\text { some related issues in their papers and a survey. }\end{array}$
\end{tabular}

(C) Copyright 2021

How to cite (in APA Style):

Istiani, I., \& Anam, Z. (2021). Integrating Peace Education in Literature Class. Rainbow : Journal of Literature, Linguistics and Culture Studies, 10(1), 48-56. https://doi.org/10.15294/rainbow.v10i1.46147

\section{INTRODUCTION}

Most of the histories of any nation have always been about wars and conflicts where peace is always challenged as well as fought for. Although current modern societies do not go to war with one another, the peaceful condition is not automatically prevailed in the world. Peace remains a desirable condition of many countries. Recently, terrorism and extremism have taken place in several countries, leaving an unfavourable impression that some religion "allows" for attacking and killing innocent people from other religions. Thus, it creates a domino effect that other unattacked countries also feel no longer safe. Peace is an attempt and a condition that many governments try to impose on their countries.

In peace studies, experts divide peace into two types: negative peace, and positive peace. (Galtung 1983; Reardon 1999). Negative peace refers to the absence of war, but with the high possibility of conflicts due to social and economic injustices, such as cases triggered by a social gap, racism, discrimination, hate speech, high crime rates. The existence of positive peace does not only refer to the absence of war but also the presence of social and economic justices. Thus, positive peace can lead to prosperity, freedom, and justice.

If we refer to the definition above, most countries are in the negative peace phase; we 
barely find countries that have already achieved a positive peace state. A country does not only ensure its people's safety, but it should also guarantee people's prosperity. Unfortunately, prosperity is not something automatically attached to a country once it gains its independence; prosperity involves many political and societal strategies by considering supporting rules and regulations. However, the concept of negative peace remains challenging since no country is free from conflicts arising due to social gaps, racism, discrimination, and/or crimes.

Aside from political power and governmental policies that can determine its country's wealth and prosperity, people also have the power to turn their "negative peace" into "positive peace" by bringing awareness to social and economic injustices. One of the ways is through peace education.

To create or maintain peace, practitioners have called for peace education. It becomes a universal issue since it has been addressed by various levels of organizations, starting from local organizations such as non-profit NGOs, formal institutions, until the United Nations (UN), specifically under its branch; United Nations Educational, Scientific and Cultural Organization (UNESCO).

There are numerous definitions of peace education, one of them is "The process of promoting the knowledge, skills, attitudes, and values needed to bring about behavior changes that will enable children, youth and adults to prevent conflict and violence, both overt and structural; to resolve conflict peacefully; and to create the conditions conducive to peace, whether at an intrapersonal, interpersonal, intergroup, national or international level," (Susan Fountain 1999). Peace education is expected to instill learners in behavioral changes so that the future's peace condition can be ensured.

Meanwhile, Harris (2007) shows a much simpler definition of it. He believes that "Peace education refers to teachers teaching about peace: what it is, why it does not exist and how to achieve it." Learners must recognize what peace is, what factors that influence the deterioration of peace, and what strategies that they should use to create, achieve or maintain peace.

Peace Education Curriculum embodied peace education also should consider several factors of the region that it will apply to, such as historical background, cultures, costumes, and also ideology. For example, in Aceh, a special region in Indonesia that implements Islamic laws in its governmental system and communal life, peace education is referred to as "the teaching about the divine natural law of plurality and an equitable social interaction constitutes a form of Islamic teaching". Therefore, as a region that implements religious laws, Aceh has to include Islamic teachings in its peace education (Husin, 2002).

Besides the factors above, peace education in intractable conflicts has its principles and conditions so that it can succeed. Intractable conflict is a conflict that has lasted over 25 years that has been arguing over real goods, from natural resources until territories, (Bar-Tal, et. al, 2009). Thus, the peacebuilding in the community that has a long intractable conflict should fulfil two sets of conditions: political-societal conditions and educational conditions. The first set on the political-societal conditions comprises of 1) the direct progress toward peace, 2) the majority support for the peace process, and 3 ) the readiness for reconciliation in the peace process. The second set on the educational condition consists of 1) full support from the highest educational authority, and 2) well-established supportive policies, regulations, and planning (Bar-Tal, et. al, 2009).

Peace education has been deeply explored by many researchers interdisciplinarily as well as from various approaches. There are three approaches to explore how education can contribute to peacebuilding (Wahyudin, 2018). The first is a knowledge-based subject approach where peace education is considered as a special subject formally taught in the classroom setting. The second is the skills and attitudes approach where peace education is transformed into classroom activities so that students attain certain expected behaviors such as tolerance. The third is the combination of knowledge, skills, and attitudes. It is believed that students must be aware of aspects 
of peace and conflict while they are equipped with skills such as problem-solving and negotiation.

To assure that education can lead to peace construction, it requires more than just a formal classroom situation. Political, social, economic, and security are some of the factors that contribute to the success of peacebuilding through education (Thompson, 2015). Thus, the integration of those supporting aspects is highly expected to meet the satisfying outcome of peaceful conditions in one country.

One of the examples of learning integration is between peace education and the teaching of history. If a student only learns the great things about his homeland, which can be heavily influenced by propaganda, his patriotism can turn into xenophobia, even racism. Traveria (2013) proposes to divert the focus of teaching history from political and military issues to the social and economic history of the world. The curriculum should bring awareness for children and teenagers on the social environment, democratic values moral, and intellectual criticism.

A study on integrating peace education into language teaching was conducted by Zamalieva (2020). Although the study did not find the effectiveness of peace education inserted in the English language lesson, the peace education could create a safe and pleasant atmosphere in the classroom that students showed their enthusiasm and cooperation in learning.

Another integration to bring peace education to a classroom is through studying literary works. Azcona (2009, p. 264) believes that literature:

"looks after beauty as a value and has the height in its point of view enough to bring a panoramic view of reality to the reader, a synthesis not separated, in the better cases, from a moral message. It has a power: to modify the mind in immediate moment and not in decades, like traditional and even systematic education."

She criticizes that education solely cannot keep up with the fast unwanted consequences of Millennium progress that it needs to be integrated with literature.

On this point, researchers agree with the pro literature circle who argues that literature provides appealing and authentic materials to motivate students whilst broadening their cultural awareness that is part-and-parcel in language learning (Dewi, 2019). Literary works that can be used to teach peace education usually the ones that narrate wars and conflicts. Teaching war literature as a part of peace education strengthens historical memories and societal beliefs to prevent similar conflicts. Students can learn "skills and strategies of problem-solving, conflict resolution and peace making" from "well-organized and frequent exposure to literature" (Nair \& Nath, 2009). Literature can bring a more alive and captivating condition to the classroom when discussing wars and conflicts because literary works are usually written in less serious ways despite how serious the topics are addressed.

Similar to Nair \& Nath, Powers (2007) suggests that in teaching peace education, literature should be an integral part. Learning war from history class cannot cover the whole truth about the war itself. Literature may reveal a deeper truth through metaphoric representation and detailed descriptions that history textbooks do not offer.

Taken from Peace Education Program (PEP) Model (Kester 2008), the goals of peace education are 1) to value diversity so that students are aware that differences are what makes each person unique; 2) to increase democratic participation as a part of nationalism when students realize that they play important roles as citizens; 3) to develop empathy for others since humans are social creatures who mutually need each other; 4) to understand consequences evolving from actions so students learn responsibilities; 5) to create peaceful environments as the ultimate goal of education.

The goals above can be summarized as students' increasing empathy and participation to create peaceful environments.

In this study, the literary works that were used to give students comprehension of peace concepts were To Kill a Mockingbird (TKAM) and The Kite Runner (TKR). The background is quite dissimilar in the presence and absence of war, but they are both similar in terms of conflicts and 
injustice settings. They deal with racism and discrimination where inequality persists.

TKAM, set in a fictional town of Maycomb, Alabama, was in intense segregation where white and colored people were always separated in terms of facilities, infrastructure, and even regulations. TKAM, written by Harper Lee in 1960, received instant success upon publication. The book narrates some serious issues such as rape and racial inequality on which some parts were based on Lee's childhood life. TKAM is commonly read in middle and high schools in the USA due to the messages of tolerance and respect that the novel delivers.

Despite the massive use of TKAM in middle and high schools in the USA (Macaluso, 2017), Ako-Adjei (2017) suggests that American schools stop using TKAM as one of the primary readings. The arguments are based on some inaccuracies of portraying the real racisms and discrimination cases that African Americans have been encountering which were far cruel than what TKAM portrayed. TKAM addresses the racism issue as a sporadic crime by an awful poor man (Bob Ewell) instead of addressing it as systematic violence.

The second novel used in this study was The Kite Runner (TKR) written by an AfghanAmerican author Khaled Hosseini. Unlike the absence of wars in TKAM, TKR was set in several riotous events, from the downfall of Afghanistan's monarchy until the re-increasing power of the Taliban. Its centre was the up and down relationship of a father and a son with a secret that was just revealed after the father died. Most studies on TKR are focused on racial discrimination and ethnicity problems (Hosseini \& Zohdi, 2016; Pramanik, 2020). Therefore, the objectives of the research were to investigate how peace education was integrated into the literature class and to elucidate the perception of peace education in the integrated literature class.

\section{METHODS}

This study employed a qualitative content analysis methodology. First, the researchers interpret and contextualize the literary work with peace topics to see how the stories were suitable to teach peace education by applying library research techniques that changed imagination into insight (George, 2008). Secondly, it used qualitative data to attest to the interpretative findings in the previous part.

In conducting the second part, the researchers collected students' final essays on the novels as well as a survey to ten selected students; and the respondents were requested to give opinions about the situation.

The participants came from four classes of the fourth semester of IAIN Syekh Nurjati Cirebon under the course of Literary Work Analysis. The instruments scrutinized by the students were The Kite Runner (TKR) by Khaled Hosseini and To Kill A Mockingbird by Harper Lee (TKAM) taken as a case scenario, questionnaires, and interviews.

First of all, five important factors in teaching peace education in the classroom setting as described by Wahyudin (2018) were employed to investigate the literary class integration. The factors were 1) objectives, 2) subject contents, 3) methods and strategies, 4) media or utilities, and 5) learning evaluation.

In the second part, the researchers gathered qualitative questions by collecting students' final essays on the novels as well as a survey of ten selected students. From the essay, the researchers analyzed how the students perceived peace education through their main topics. Meanwhile, from the survey, the researchers could explore how students implemented peace education in their real life.

\section{RESULTS AND DISCUSSION}

\section{Integrating Peace Education in Literature Class}

To ensure the smooth implementation of peace education in the classroom setting, the researchers chose carefully the five factors of teaching peace education by Wahyudin (2018), they were 1) objectives that students are expected to achieve as the learning outcomes,2) subject contents that are suitable for the related topics in peace education, 3) methods and strategies to 
deliver the materials, 4) media or utilities to bring more optimal learning outcomes, and 5) learning objectives to find out the effectiveness and/or the success of the whole learning process.

The first factor is objective. The targeted objectives of integrating peace education in the literature classes where students were expected to 1) gain knowledge on peace education areas such as conflicts, wars, acts of violence, genocides, stereotypes, overgeneralization, ethnocentrism, etc. and 2) master related abilities to create peace, such as negotiation, cooperation, empathy, tolerance, etc.

After reading TKAM and TKR, the students were familiar with some new terms like genocides, stereotypes, overgeneralization, and ethnocentrism. Their understanding did not stop on mere definitions of the terms, but the application of the definitions that they could find or be related to the contents of the story.

The second factor is content. The subject contents were two novels, they were: (1) TKAM by Harper Lee, and (2) TKR by Khaled Hosseini, with the following specific materials delivered to the students.

TKAM tells about racial injustice in a fictional town of Maycomb County from the eyes of a little girl named Scout. She witnesses unfair treatment in the court regarding the case of Tom Robinson who is accused of raping a white girl. Despite several facts leading to Tom's innocence, the jury still convicts Tom of the crime.

The second novel is TKR that narrates the life of a young Afghan who ran to the United States with his father when the beginning of the long history of wars broke out. Their escape brought Amir to feel guilty since he needed to atone for his past sins. The novel brought several serious topics ranging from sexism, racism, discrimination, wars, conflicts until betrayal.

At the beginning of reading both novels, students found difficulties when encountering unfamiliar words. But when they were encouraged to keep reading the novels, they found themselves enjoying the stories. Some scenes were vulgar and were deemed inappropriate to read such as raping in TKAM and sodomy scenes in TKR. However, since they were at the college level, they understood that those accidents could just happen in the real world. They learned that those things influenced the peaceful life that they wanted to create in life.

The third factor is the methods and strategies employed throughout the semester, they were: 1) weekly reading reflection to record students' reading assignments, 2) crafting a short story so that students would appreciate literary works more, 3) group discussion so students were exposed with more various ideas and opinions, 4) poster presentation to visualize their ideas on certain topics, and 5) role-play to relive some scenes taken from the novel.

In the weekly reading reflections, students wrote down their understandings or summaries of the last readings they had. Some of them went creative such as making mind mapping, drawing pictures, and other visualizations. The reflections were meant to control and monitor the student's reading progress and to assure they did indeed read the novels, not just some summaries from the internet or other sources. The example of the weekly reading is below.

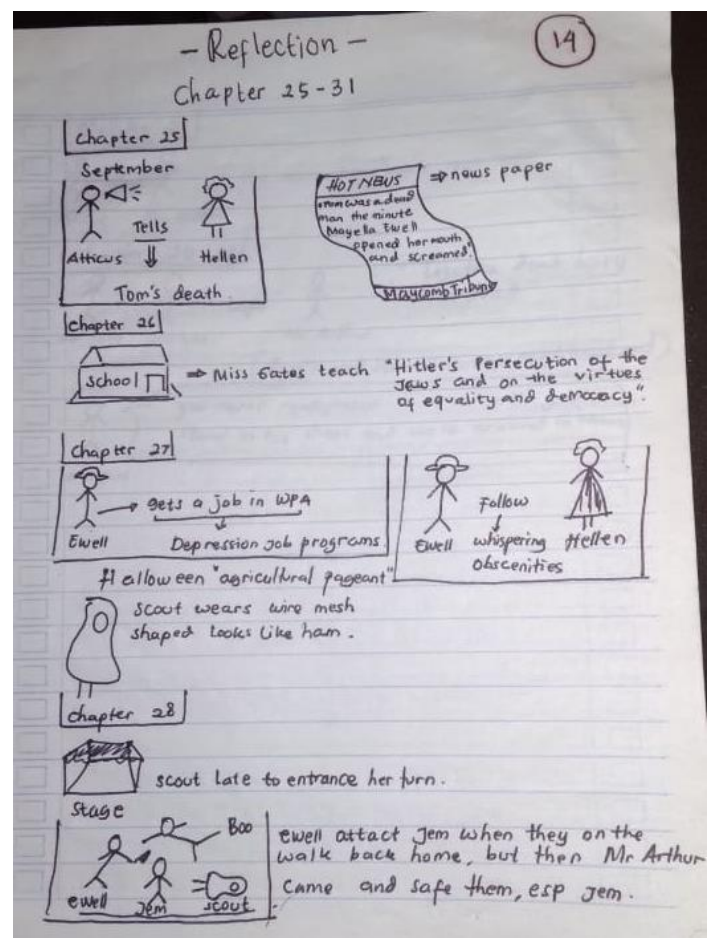

Figure 1 - An Example of Student's Weekly Reading Journal 
In creating a short story, the researchers investigated how far the stories they read influenced their imagination. It turned out that the topics of the short stories that the students wrote were not quite related to the novels. It could be due to their limited imagination on themes related to the novels such as racism, discrimination, inequality, and sexual abuses were not commonly discussed in their spheres.

The next strategy used was group discussion. In some meetings, students were assigned to groups and were asked to discuss some important topics taken from the novels. Along with the discussion, they comprehended important messages of the stories related to peace education.

Another strategy was poster presentation. Each class was divided into six groups with different topics to address, they were: law \& equality, feminism, poverty, discrimination \& racism, stereotyping, and ethnocentrism. One of the members presented the poster to the members of the other groups while the rest of the groups visited other posters. They learned from their peers on the topic of the poster that was highly related to peace education. Below is a sample of the students' poster.

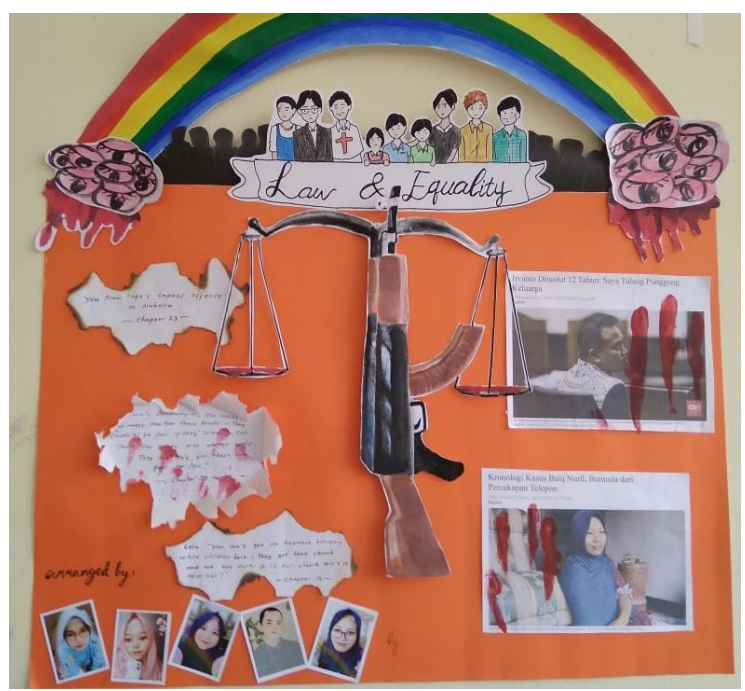

Figure 2 - A Class Poster on Law \&Equality

The last strategy was role-playing which took some important scenes taken from the novels.
By playing the roles, students could comprehend the essences of the novels livelier and interactively.

The fourth factor was the usage of media and utilities. To enrich the students' knowledge on chosen topics, the researchers managed to bring different kinds of media and utilities every week, such as newspaper clippings, videos, movies, fact sheets, flashcards, and others.

The last factor to be considered was evaluation. Learning evaluation for peace education program was taken from Momanyi (2018) elaborating on several steps critical for the achievement of the goal of peace education, they were 1) survey before and after peace education program, 2) interview to assess the program's impact, 3) focus group to examine concepts and values of peace education, 4) observation focused on the behavioral change, 5) review of school records to assess the progress, and 6) the experimental approach focused on the research implementation.

\section{Perceived of Peace Education in the Integrated Literature Class}

One of the evaluation assignments was in the form of analysis papers submitted as a final exam. Since students were free to write anything, the topics that the students were various, yet they were connected to peace literature. Below are the topics that students wrote for their final essay that the researchers categorized into three big issues, they are 1) gender inequality, 2) discrimination, and 3 ) victimization.

\section{Gender inequality}

At the beginning of the class, students thought that feminism was the same as feminine. When they read some parts when Aunt Alexandra wanted Scout to be more feminine, they were confused. After learning that feminine was attributed to what girls were expected to look like and behave in terms of appearances and characteristics while feminism was a movement to demand female is equal to male, students learned about gender inequality. It was reflected in some papers that addressed feminism and gender 
inequality in their papers. One student criticized Aunt Alexandra's upbringing style and wrote that "It was an old-style that did not suit with the feminism principle." Another student wrote about gender inequality from TKR. She realized that Soraya (Amir's wife) had been belittled by her community before she married Amir. She ran away with an Afghan man and lived together in Virginia out of wedlock. The student realized that "Women are always looked at from their pasts while men are always looked for their future."

\section{Discrimination}

Discrimination issue was addressed from various topics such as racism, religion, ethnicity, social status, and stereotypes, both in TKAM and TKR. Discrimination is highly related to peace education since it is the beginning of separation, starting from the dichotomy of in-group vs outgroup. Racism is the most talked about topic in TKAM since the story revolved around an innocent black man who was accused of raping a white woman. The blind accusation is a part of racism since the trial neglected all of the strong proofs yet gave the black man a guilty verdict. One of the students wrote about TKAM that "Whatever strong proofs that Tom Robinson had, he would be defeated because of his skin." Another student argued in his paper on TKR that "Amir let Hassan bullied by Asef because he (Hassan) was a servant, lower class than Amir."

\section{Victimization}

Another big issue that the students addressed in their papers is victimization, which is treating someone unfairly and/or making him a victim. This issue was found both in TKR and TKAM. One student argued that "Although Hassan knew that Amir did nothing when Asef abused him (Hassan), he still tried to be good to him because he knew deep inside that Amir was a good person." This is a form of victimization. Hassan realized his position as a servant; he just let him be bullied orally, physically even sexually. Meanwhile, the form of victimization that a student wrote in TKAM was "Mayella chose to blame Tom Robinson because she was ashamed of her action. She did not want people to know that she tried to seduce Tom. She strongly believed all of the people would be on her side."

The last step of the evaluation was explored through a survey distributed to ten selected students. They were asked 15 questions; 5 questions were related to TKAM, the other 5 were related to the TKR and the last 5 questions were addressed to their personal experiences and understanding. Students' answers were varied yet they showed their comprehension of the novels and their perceptions on peace education. Such as when asked about the guilty verdict by the jury for Tom in TKAM, a student wrote her argument that "It was not fair because all the proofs showed that Tom was innocent." However, another argument stated that although the verdict was not proper, it was reasonable because "If the judge decided that Tom was innocent, there would be more riot and chaos in Maycomb." The statements from both students look contradictory to each other, but they showed their comprehension of conflict in general. As stated in the last response, creating peace could not be implemented immediately without careful planning and decision to bigger conflicts.

Aside from peace education lessons found in the novels, students were also aware of some conflicts that they faced in their real life. For example, a student faced discrimination because of her hijab. She was not allowed to join a competition. To show that she could do whatever right to her, she was finally able to join Paskibraka (members of flag raisers); a more prestigious competition than the one she was refused to join. On the contrary, another student who always received special attention from her teachers because of her academic achievements admitted that "Some students hated me because I got special treatments. They did not know that I did not like to be treated differently."

Both from students' papers and surveys, it was found that students were aware that some conflicts were complicated. Conflicts could be caused by betrayal, stereotyping, wars, colonialization, and even social and economical gaps. Most of the conflicts were not just person-toperson problems; they were whole societal 
problems. Some conflicts created victimization and scapegoats where innocent people were to blame and even punish.

\section{CONCLUSION}

As observed through the students' evaluation projects, both novels were proved to be effective in delivering issues and themes around peace and conflicts so that students were familiar with the essence of peace education. Students were introduced to terms that might be their very first time hearing them, such as racism, discrimination, victimization, stereotypes, generalization, ethnocentrism, guilt, scapegoating, etc. Students also learned further on tolerance, equality, fairness, justice, negotiation, peace-making, peacebuilding, and problem solving through some methods and strategies in teaching the materials. In their real life, some students admitted that they encountered discrimination and stereotyping, either as a victim or as a perpetrator. However, students should be exposed more regularly to real cases of conflicts in their surroundings so that they are aware that the world needs more peace education and its application. Further research interest may explore the implementation of peace education in students' real life after they are exposed to the materials.

\section{REFERENCES}

Ako-Adjei. (2017). Why it's time schools stopped teaching To Kill a Mockingbird. Indiana University Press on behalf of the Hutchins Center for African and African American Research at Harvard University. (122): 182-200. Downloaded from https://www.jstor.org/stable/10.2979/transitio n.122.1.24

Azcona, M. C. (2009) Peace Education through literature. In A. Ahorni (ed.) Peace, Literature, and Art, 1(1). UK: EOLSS/UNESCO.

Bar-Tal, D., Rosen, Y., \& Nets-Zehngu, R. (2009). Peace Education in Societies Involved in Intractable Conflict: Handbook on Peace Education Routledge. Accessed on: 16 Jul 2019. https://www.routledgehandbooks.com/doi/10. 4324/9780203837993.ch3
Dewi, N. (2019). TEACHING LITERATURE WITH TOUGH TOPICS IN ELT CLASS: BULLYING AND BIGOTRY. LLT Journal: A Journal on Language and Language Teaching, 22(1), 66-77.

Fountain, Susan (1999). Peace Education in UNICEF. UNICEF: New York.

Galtung, Johan (1983). Peace Education: Learning to Hate War, Love Peace, and to Do Something About It. International Review of Education. 29 (3).

George, M. W. (2008). The Elements of Library Research: What Every Student Needs to Know. Princeton: Princeton University Press.

Harris, Ian M. (2007). Peace Education Theory. Journal of Peace Education. 1(1). 5-20.

Hosseini, Khaled (2003). The Kite Runner. Riverhead Books: New York.

Hosseini, A. S. \& Zohdi, E. (2016). The Kite Runner and the problem of racism and ethnicity. International Letters of Social and Humanistic Sciences, 74: 33-40. doi:10.18052/www.scipress.com/ILSHS.74.33

Husin, A., (2002). Peace Education Curriculum. Translated by Darni M. Daud, Ph.D. Edited by Asna Husin, Ph. D. Reviewed by Karim Douglas Crow, Ph. D. Sponsored by: UNICEF NonViolence International AusAID.

Kester, Kevin (2008). Developing Peace Education Programs: Beyond Ethnocentrism and Violence. South Asian Journal of Peacebuilding. 1 (1).

Lee, Harper. (1960). To Kill a Mockingbird. Philadelphia: J. B. Lippincott Company.

Macaluso, M. (2017). Teaching To Kill a Mockingbird today: Coming to terms with race, racism, and America's novel. Journal of Adolescent \& Adult Literary, 0 (0): 1-9. Doi: 10.1002/jaal/678

Momanyi, Rose Kemunto (2018). Monitoring and Evaluation of Peace Education and Implementation in Primary Schools in Uasin Gishu Country Kenya. International Academic Journal of Social Sciences and Education. 2 (1). 168180.

Nair, Sreeja S. and Baiju K. Nath (2009). Integrating Principles of Peace Through Effective Transaction. Columbus, Ohio: ERIC Clearinghouse.

Powers, J. M. (2007). Teaching war literature, teaching peace. Journal of peace education, 4(20): 181-191.

Pramanik, S. R. (2020). The problem of ethnicity in Khaled Hosseini's The Kite Runner. Smart Moves Journal IJELLH, 8 (9). DOI: https://doi.org/10.24113/ijellh.v8i9.10777

Reardo, Betty A. (1999). Peace Education: A Review and Projection. Peace Education Reports. 17. 
Thompson, Stephen (2015). Links between education and peace. Helpdesk Research Report. www.gsdrc.org

Traveria, G. T. (2013). History teaching and peace education in a time of crisis: How can we build a shared future based on dialogue and peace? Policy paper Institut Catala Internacional Per La Pau, 9.

Wahyudin, Dinn (2018). Peace Education in The Context of Education Sustainable Development (ESD). Journal of Sustainable Development Education and Research, 2 (1), 21-32.

Zamalieva, A. I. (2020). Promoting peace education via language teaching. Proceedings IFTE-2020: $2885-$ 2893. doi:10.3897/ap.2.e2885. 